\title{
Fusobacterium necrophorum subspecies funduliforme
}

National Cancer Institute

\section{Source}

National Cancer Institute. Fusobacterium necrophorum subspecies funduliforme. NCI

Thesaurus. Code C86402.

A subspecies of anaerobic, Gram-negative, rod shaped bacteria in the phylum

Fusobacteria. This subspecies is non-spore forming, lipase and catalase negative, indole positive, does not hydrolyze esculin or starch, does not reduce nitrate, does not produce hydrogen sulfide, and does not produce acid from carbohydrates. F. necrophorum subsp. funduliforme, also know as biovar B, is found in the intestinal tract of animals, but is known to cause infections in both animals and humans. 